\title{
The Polling Debate in Kenya's 2007 Elections
}

\section{Patrick Mutahi}

\section{OpenEdition}

\section{Journals}

Electronic version

URL: https://journals.openedition.org/eastafrica/701

ISSN: 2790-1076

Publisher

IFRA - Institut Français de Recherche en Afrique

Printed version

Date of publication: 1 April 2008

Number of pages: 151-168

ISSN: 2071-7245

\section{Electronic reference}

Patrick Mutahi, "The Polling Debate in Kenya's 2007 Elections", Les Cahiers d'Afrique de l'Est / The East African Review [Online], 38 | 2008, Online since 19 July 2019, connection on 09 December 2021. URL: http://journals.openedition.org/eastafrica/701

This text was automatically generated on 9 December 2021

Les Cahiers d'Afrique de l'Est / The East African Review 


\section{The Polling Debate in Kenya's 2007 Elections}

\section{Patrick Mutahi}

1 This paper discusses opinion polling in Kenya's closely contested 2007 Presidential elections. It analyses the relevance of public opinion in Kenya's emerging democracy in the context of the closest presidential contest in Kenya's history.

2 The paper notes that the country is still in transition from a long historical experience of authoritarianism and dictatorship including a period of a "culture of silence," to freedom of expression, and this poses a strong challenge to pollsters.

3 Results of several opinion polls conducted by local research firms before the 2007 General Elections elicited mixed reactions from politicians depending on the results. Candidates who ranked high on a particular poll, understandably, consecrated its legitimacy; on the other hand "losing" candidates were quick to cast aspersion on the reliability and validity of the survey results.

4 There is therefore need for mechanisms to ensure that error-prone or impartial poll surveys that fail to correctly predict election victories do not risk fueling post-election conflict.

5 Opinion polls in Kenya are becoming a permanent feature of Kenya's politics and will continue to serve as a double-edged blade with the potential of expanding the space of democratic expression. On the other hand, they can be a risk for its fragile democracy.

\section{Introduction}

6 The public opinion poll continues to have a prominent role as a source of information in different societies of the world. As such, it is important that users are conversant on how to evaluate and place this type of information into context.

7 Politics has always been a topic of intense discussion and debate. In fact, so much has the dependence on opinion polling in politics increased in the last few decades in some 
liberal democracies that where the media is referred to as the "Fourth Estate," then some recent studies reckon opinion polling to be the "Fifth Estate."

After 2002, pollsters in Kenya started openly conducting and releasing opinion polls to the media. As expected, the polls have elicited mixed reactions. Once opinion polls results are released, charges and counter charges on the efficacy and genuineness of various polls are made by opposing political parties. This may reflect the high level of competition and dependence on the polls by various political parties, in using them as campaign inputs. It is not uncommon for politicians to use favourable findings in their election speeches.

Each election is fought on certain issues and themes, which are propped up by political parties, electorate, interest groups, and media. Opinion polls reflecting the opinions and expectations of the people on various issues can bring about a meaningful political debate, which undoubtedly will strengthen the political process.

Whenever, an opinion poll is published, some people have expressed doubts whether it could have an effect in encouraging the voters to vote for the projected winner, or provide an "underdog" effect, possibly evincing sympathy and support for the apparent loser. While the polls themselves attract attention over sample size and methodology, no serious research, however, is conducted in Kenya to gauge their impact on the election outcome.

$1157.4 \%$ of people polled by Sunday Nation revealed that they had faith in the opinion polls while $42.6 \%$ did not believe them. ${ }^{1}$ Among those who supported opinion polling, 52.3\% said the results reflected the reality on the ground. This statistic would indicate that large majorities lay persons, policy professionals and leaders, see the science of polling as potentially useful to the process of Kenya's emerging democracy.

12 Kenya National Bureau of Statistics (KENBS) ${ }^{2}$ and its constitutive Act (Statistics Act, 2006) regulate opinion polling in Kenya. The Act stipulates that "any person who knowingly compiles for issue any false statistics or statistical information shall be liable on conviction to a fine not exceeding Sh 100,000 or to imprisonment for a term not exceeding one year."

The Act became law in September 2006 and as this was the eve of an election year, the move was seen as an effort to rein in pollsters. It was feared that it would keep politically-based opinion polls away from the public where they were not in the Government's favour. However, this Act has never been invoked.

This paper will locate the power of opinion polling on the psyche of the electorate in Kenya. It describes the relationship between opinion polls and the 2007 Presidential elections. Lastly, it questions whether the growing industry of opinion polls requires effective poll watchers to ensure a high standard of professionalism.

\section{Impact of opinion polls: theory and evidence}

The fear of undue influence on voters is the reason why many democracies have discussed and/or regulated the publication of opinion polls concerning elections.

Kenya's 2007 General Election registered the highest number of opinion polls ever conducted in Kenya. This elicited mixed reactions from the electorate and politicians alike. This controversy raises two scenarios: the manipulative power of the opinion 
polls on the psyche of the electorate, and secondly, the genuineness and scientific basis of various polls.

Public opinion polling is rooted in the virtuous and noble principles of democratic theory. In The Pulse of Democracy (1940), George Gallup and Saul Rae credibly assert that polling helps to destroy tyranny and promote democracy because pollsters go straight to the people and ask them what they think about their political leaders, their policies, and about various other public policy concerns.

In his essay "Why Respond to Polls? Public Opinion Polling and Democracy," Robert Shapiro argues that polls are a public's best means for balancing the power and influence on interest groups and political action committees. ${ }^{3}$ It is thus consistent with democratic practices and principles and can be used effectively to help promote a democratic society.

19 Vincent Hutchings in Public Opinion and Democratic Accountability ${ }^{4}$ challenges the pessimistic, generally elitist view of democracy that casts doubts on the public's capacity to make informed democratic choices. His study finds that voters are highly responsive when their issues are raised in campaigns, suggesting that elite efforts at controlling the political agenda raise the political temperature of major constituencies.

The emergence of the "rational public" as a concept in mass public opinion research has shifted attention away from the notion of the public as poor decision makers. Recent scholarship on the nature of public opinion has shown it to be stable and rational, and these authors claim it as being viable for basing policy decisions upon. ${ }^{5}$ This is especially so in Africa where the leaders are seen as "fathers" and are referred for advice, even for the most mundane tasks. ${ }^{6}$

21 In an earlier work, Shapiro and Benjamin Page elaborate on the idea of collective wisdom. ${ }^{7}$ The argument for collective wisdom seems to hold much weight and, would lend itself to the fact that polls are in fact a legitimate and useful means for harnessing the collective policy preferences of the public. If this view is accepted, a reader can subsequently see that the problems associated with polling are not inherent in the science of polling itself, but rather the use of polls for illegitimate purposes. Therein lies the detriment to democracy.

22 From this point it will be easier to ascertain how polls can be used to positively influence democratic debate on policymaking and fulfill the democratic process to a greater extent.

Measuring polling effects is problematic since there are several ways in which the publication of a poll can change a voter's electoral choice. The famous bandwagon effect assumes that a political party or candidate gains by a positive polling trend. The opposite of the bandwagon effect is the underdog effect in which people vote out of sympathy, for the party perceived to be "losing" the elections.

24 At other times respondents might prefer not to answer questions they find sensitive. In Kenya for example when doing surveys on sensitive subjects like same sex marriages or abortion one is highly likely to experience what has been termed a spiral of silence.

Since the popularization of public opinion polling, the issue of response rates has been a recurrent methodological concern. ${ }^{8}$ It has gained prominence due to the escalating importance of public opinion polling in politics. Sometimes response rates can reach levels that are so low that a survey's representativeness is called into question. 
Another outcome is the "boomerang effect" where supporters of a candidate shown to be winning feel that s/he is "home and dry" and that their vote is not required, thus allowing another candidate to win.

Pollsters in Africa face numerous limitations. In the rural areas especially, the language barrier is a hindrance to getting accurate information. Most people are not fluent in English, French or Portuguese and their opinion is predictably left out of surveys. Others are pollsters' generic problems of using unsound methodology and biased sampling.

It matters greatly how the pollsters ask their questions. Questions can be misleading or phrased to prompt a certain response. Additionally, questions posed in different ways can get very different results.

9 Sometimes, respondents offer opinions on subjects about which they have not thought much and do not care at all. People sometimes answer pollsters' questions just to be polite-because they believe they probably ought to have an opinion. That gives pollsters a lot of room to "manufacture" opinion, especially on issues of narrow rather than wide concern.

Pollsters are not charitable patrons and they are actually people in business who may sometimes deliberately engineer results in order to generate a certain result to please their clients. In Kenya, surveys have opened new revenue avenues for research companies, which in 2007 stood to collect a staggering Sh 3 billion. The cost of an opinion poll depends on a number of factors including the kind of information a client wants and sample size. It generally costs a minimum of Sh 1 million to do a sample of 1,000 people spread across the country.

"In Kenya, campaigns are finance intensive ventures. That is why it makes sense to know how you could fare before you commit any money. That is why serious contestants could be willing to subscribe to the verdicts of an opinion poll before committing their money to proper campaigns," says Dr Carey Onyango, Vice-Chairman Centre for Multiparty Democracy-Kenya.

Hence when opinion polls are tilted during elections to favour certain candidates this has major implication for democracy and governance if voters are influenced into making the wrong choices.

When interest groups commission pollsters to ask leading questions to gather "scientific" proof that the public agrees with whatever demand they are making on government, they demean polling and mislead the public. When political consultants use information gathered through polling and focus groups to camouflage their clients' controversial policies with soothing, symbol-laden, and misleading rhetoric, they frustrate democratic deliberation.

4 Thus, it is desirable that the public be protected from unsound election polls and from illegitimate pollsters. While the trained eye may be able to distinguish between valid and invalid election survey results, the general public will benefit from some guidance on how to deal with election polls. There are however many different factors determining why and how people vote, and no one would argue that opinions polls alone are a major cause. These include party strategies and media bias.

The above represent only a few of the reasons put forth by proponents of polling and merely serve as a general introduction to the claim that public opinion polling is, a legitimate practice. 


\section{History of silence} results. and cultural issues. Uganda and Zambia," says Waititu. ${ }^{9}$ emerging polling potential. Newspaper. same time, the Africa.

Kenyans have never been adept at predicting election outcomes before 2002 few opinion polls were being done. Due to censorship during the KANU era, many firms feared conducting opinion polls and media organizations could not even publish the

In 1997 and 2002, a few opinion polls were conducted, which predicted that the then President Daniel Moi would win the election but none were made public. After 2002 with the increased democratic space, opinion polls have been regularly conducted with two target groups: the general public and business leaders. General public opinion polls seek to provide systematic and representative public perceptions on social, economic

The Steadman Group is considered the pioneer of opinion polling in Kenya with its Business Leaders' Confidence Index (BLCI), which collects business leaders' perceptions towards the economy. The BLCI is now widely used by Government and business leaders in a number of countries in Africa. "We decided to take opinion polls beyond the public to businessmen and it is paying off. Regular content on these polls include politics, crime, consumer confidence, government performance rating. They have been conducted in Kenya,

The country has seen a gradual increase in the use of opinion poll data to inform social, economic and political issues. Another research company, Consumer Insight (CI) has also developed a research methodology called Target Group Index (TGI) that is specifically geared to establish targeted consumer behaviour.

The fact that Kenya is now viewed as ripe market for opinion polls market started to manifest in 2005 when International Research Network Ltd ceded its operations in the country and gave way to a local firm called Research and Market Services Ltd (RMS). The move was meant to position the new company to better tap into the country's

The Steadman Group conducted opinion polls a month apart (October and November 2005) just before the 2005 constitutional referendum. The polling results predicted that only $43 \%$ per cent of the electorate would support the draft constitution, which came to pass as the draft constitution was rejected by $57 \%$ of the actual voters.

Since then, Steadman Group has become influential in shaping public perception and its findings are deemed critical in tipping the balance of opinion on national issues.

However, the 2007 elections saw the entry of three other pollsters-Infotrack Harris, Strategic Research and Consumer Insight all commissioned by The Daily Nation

In July 2007, Infotrak Research and Consulting (IRC), sealed a deal with a US company, Harris Interactive Global Network of research companies in New York to bring the Harris Poll-one of the world's longest running opinion polls to Kenya. Around the

4 Steadman Group announced the commencement of a fortnightly opinion poll it would use to gauge people's perception about a variety of issues, including politics across East 
These strategic moves are a response to market demands, driven by several politicians who are breaking from tradition and commissioning their own opinion polls, to gauge voters' perception and thus help them chart their course.

The 2007 General Election registered the highest number of opinion polls ever conducted in post-independence Kenya. The surveys elicited different reactions from the public and this has posed new challenges to polling in Kenya.

\section{7 elections: a statistical dead heat}

Although there were nine Presidential candidates, the 2007 contest involved three main contenders, the incumbent president Mwai Kibaki sought a second term as the candidate of the Party of National Unity. His main challengers were Raila Odinga of Orange Democratic Movement (ODM) and Kalonzo Musyoka of Orange Democratic Movement-Kenya (ODM-Kenya).

Similar to the 2005 referendum, the 2007 poll was seen as a contest between Kibaki and Raila. Then as now, the constitution and economy were the most important issues. Ethnicity largely informed voting patterns in the country.

Presidential Public opinion polls conducted before the 2007 elections sought to predict how the nation would have voted were an election held on the day of the survey. In effect, they reported the current state of play between the rival parties. Throughout the campaigning period, the pollsters predicted a very tight race, which would be determined by the voter turn out. However, these were disputed by the main challengers often citing ethnic and political bias of the pollsters.

Two major reasons lead to questionable poll results: unsound methodology and/or deliberate intent to release to the public fabricated or pre-determined outcomes. The glaring huge gaps between results of the different pollsters while they were polling the same presidential candidates and topical issues were suspect. "This was largely due to various firms using different sampling frames," says Arthur Bore. ${ }^{10}$

Since 2006 President Kibaki has been enjoying high ratings but it should be recognized that it a period during which ODM was experiencing a power struggle between Kalonzo Musyoka and Raila Odinga. When Raila was chosen the ODM flag bearer, the polls started favouring him over the incumbent. However, there were remarkable variation margins between the different pollsters all through the campaign period.

For example, on 17 November 2007, Raila garnered $40.7 \%$ in the Consumer Insight poll, which gave President Kibaki $41.4 \%$. Kalonzo of ODM Kenya remained in third place with $14.7 \%$.

4 The results were not anywhere replicated by the two other pollsters. Infotrak gave Raila a 10-point lead over the President-Odinga 47.3\%, President Kibaki 37\% and Kalonzo 13.7\%. Strategic PR had Mr Odinga ahead of President Kibaki by $11 \% .{ }^{11}$

In a Steadman poll released on the same week, the gap between Raila and President Kibaki was recorded to be four points. Raila was recorded to have $45 \%$, Kibaki at $41 \%$ and Musyoka at $11 \%$.

While explaining the different variations, Steadman Managing Director George Waititu explained that they had changed their sampling method from population size to registered voters per province following the closure of the Electoral Commission 
register. This, according to Waititu "was the best method since it is based on population concentration in the various regions." 12 This meant that the province with the higher number of registered voters had a higher representation in the final sample that was selected at random.

However, Strategic Public Relations had been using the voter registration figures all along and has always had a much larger gap than Consumer Insight and Steadman group.

Infotrak, which had been using population size, and in the wake of the Steadman Group results decided to test their own figures for The Daily Nation poll by working on two different sampling methods; their regular one based on population and a second one based on registered voters per province. The difference was negligible.

Although the President closed in slightly on R. Odinga, the difference was insignificant and what might have been noteworthy was Kalonzo's share of the vote moved up from 13.7 to $16 \%$, at the expense of both front-runners. This might be explained by the fact that whereas Kalonzo's stronghold, Eastern Province, has 15\% of the population, it has $17.6 \%$ of the registered voters. ${ }^{13}$

60 These huge variations led to consistent allegations that the "polls are flawed and inaccurate" even leading to Kalonzo Musyoka saying that "there is only one week left before Steadman credibility is put to test when Kenyans cast their vote and results made known." 14

61 Candidates who rank high on a particular poll, understandably, consecrate its legitimacy; on the other hand "losing" candidates are quick to cast aspersion on the reliability and validity of the survey results. "Publicly they will not show it but they treat our polls seriously. Some send agents to come and get copies of the poll results from our offices," said one informant. ${ }^{15}$ The mere fact that politicians try to analyse and understand the poll results albeit discreetly shows that to some extent they believe they are legitimate but in order not to disappoint their supporters, they publicly disown them.

On 9 November 2007 Steadman Group released opinion polls that showed Kibaki closing the gap on Raila. However, the ODM presidential candidate scoffed at the polls saying they were not a true reflection of the reality. ODM-K summit member David Musila equally casted doubt on them saying there is no way their candidate could be polling $11 \%$. On the other hand, PNU, which according to the polls was gaining lost ground, welcomed the polls exuding confidence that Kibaki would win. ${ }^{16}$

Opinions are "ripples on the surface of the public's consciousness" 17 and therefore shallow and change easily, in contrast to attitudes and values which lie deeper below the surface and are slow to change. Thus, results of opinion polls change over time and shifts in opinion have been recorded many times in many places.

Opinion polling has been so misunderstood and unfortunately maligned by so many Kenyans and criticizing pollsters has almost developed into a national pastime. Since polling is a relatively new concept in the country, the common criticisms many Kenyans have with it are based more on emotional biases, political agenda, and plain ignorance than on a rational rejection of polling based on a thorough understanding of polling methodologies and how polls are actually used in democracy.

65 Apart from attacking the credibility of pollsters, politicians also questioned their professional training, ethics and objectivity. This has potentially serious implications for the profession of public opinion research. 
Party politics in Kenya are, first of all, the politics of ethnic identity. The change of power in 2002 did not transform that pattern-the change resulted from a reconfiguration of ethnic politics rather than its transformation. Political parties exist primarily as voting machines for "big men" who see a chance to become president and use the ethnic appeal for mobilization of voters. Party programmes and mechanisms of intra-party opinion formation play a negligible role. This explains the fluidity in party political spectrum and the struggles for power within the parties, largely based on ethnicity.

73 The public discussion of opinion polls is not always very well informed. Discussing the authenticity of opinion polls, one Karanja Gitau from the United States wrote: “It's not accurate because they interview less than 3,000 voters whereas we have more than 14 million voters. 3,000/14 million $=0.0002143=0.021$ percent. If polls can work in USA, it doesn't mean they'll be accurate in Kenya. We use ballot paper/boxes they use electronic voting." 22 
Such sentiments were widely articulated by the general public. "I don't think that the polls are reflecting the situation on the ground. There is no way any fair poll could put Raila and the president that close. The smallest difference should be 20 points, Raila being ahead." 23

hows that most politicians and the general public do not acknowledge the specific methodological techniques that make modern polls so accurate and reliable, or how they can be employed to promote a healthier, more responsive democratic society. Pollsters agree that polls can correctly predict the outcome of a general election, but only if the research adheres to strict scientific methods to minimize bias and errors. presented as poll results are correct and has passed the rigorous professional requirements. Such a body would also educate the masses on the politic of polling as well as arbitrate in case of disputes.

7 Such a role is spelt out in the Statistics Act, which requires pollsters to submit not just their plans to conduct the survey according to Section 18(1) but also submit such results to the KENBS as provided by Section 19. While the Kenya Government may have had good intentions enacting this clause, it is vital that the private players regulate themselves. This will erase the illusion that the Government is trying to muzzle them from releasing poll results which are against it.

Since opinion polling will play such an important role in Kenya's political future, it is important that necessary measures are taken to not only educate the public on the role of polls, but also establish mechanisms of reining in rogue pollsters.

\section{Conclusion}

This paper has traced and discussed the place of opinion polling in Kenya. It has noted that due to the censorship prevalent in the KANU era, conducting opinion polls is a relatively new industry.

During the 2007 general elections, there was a remarkable sudden increase of opinion polls, which left many Kenyans asking questions regarding authencity of data. As such, it is necessary that the industry urgently takes steps to regulate itself and get rid of illegitimate pollsters.

81 This is more important noting that opinion polls can influence perception of a particular candidate and that is why those leading welcome the surveys, with those trailing dismissing them. It is only by having effective pollster watchdogs that Kenyans can tell which pollster actually predicted the results within the stated margins of error.

\section{BIBLIOGRAPHY}

BRATTON, M., MATTES, R., GYIMAH-BOADI, E. (2004). Public Opinion, Democracy, and Market Reform in Africa. Cambridge: Cambridge University Press. 
BRATTON, P.A., BOWSER, G., TEMBA, J. (1999). 'The Effects of Civic Education on Political Culture: Evidence from Zambia,' World Development 27(5) (May), 807-24.

GROVES, R.M., COUPER, M.P. (1998) Nonresponse in Household Interview Surveys. New York: John Wiley and Sons.

HUTCHINGS, V.L. (2003). Public Opinion and Democratic Accountability: How Citizens Learn about Politics. Princeton: Princeton University Press.

MILLER, K. (2005). Communication theories: perspectives, processes, and contexts. (2nd ed). New York, NY: McGraw-Hill.

PAGE, B.I., SHAPIRO, R.Y. (1992). The Rational Public: Fifty Years of Trends in Americans' Policy Preferences. Chicago: University of Chicago Press.

POWLICK, P.J. (1995). 'The Sources of Public Opinion for American Foreign Policy Officials.' International Studies Quarterly 39 (4): 427-51.

WA-MUNGAI, M. (2007) 'Tusker Project Fame: Ethnic States, Popular Flows.' Journal of Eastern African Studies 1 (3): 338-58.

WORCESTER, R.M. (1993) 'Public and elite attitudes to environment issues,' International Journal of Opinion Research 5 (4): 315-34.

\section{NOTES}

1. 'Most Kenyans believe pollsters.' Sunday Nation, December 9, 2007 p 2. In this survey, 2120 people distributed countrywide were interviewed.

2. The KENBS took over from the Government Department Central Bureau of Statistics.

3. Shapiro, Robert Y. 'Why Respond to Polls? Public Opinion Polling and Democracy.' http://www.publicopinionpros.com/features/2004/nov/shapiro.htm [Not available. Archive].

4. Vincent L. Hutchings Public Opinion and Democratic Accountability: How Citizens Learn about Politics. Princeton, Princeton University Press, 2003 (171 pp).

5. Page, Benjamin I., and Robert Y. Shapiro. 1992. The Rational Public: Fifty Years of Trends in Americans' Policy Preferences. Chicago: University of Chicago Press. Powlick, Philip J. 1995. The Sources of Public Opinion for American Foreign Policy Officials. International Studies Quarterly 39 (4):427-51.

6. The oft quoted remark is when politicians "advice" farmers to plant since the rains have come.

7. Shapiro, Robert Y, ibid.

8. Groves, R.M. and M.P. Couper (1998) Nonresponse in Household Interview Surveys. New York: John Wiley and Sons.

9. 'Billions from opinion polls,' East African Standard, July 3, 2007

10. A research officer at Steadman Group. Interview conducted on $1^{\text {st }}$ November 2007.

11. Consumer Insight and Strategic Public Relations were basing their sampling on the number of registered voters per province rather than population size, as Infotrak was.

12. George Waititu's address to the press, November 9, 2007. 
13. 'Latest surveys forecast tight race for State House.' www.nationmedia/elections, Nov 17, 2007 [https://www.nation.co.ke/lifestyle/1190-217038-g17v2xz/index.html. Archive].

14. East African Standard, December 19, 2007.

15. Informant gave interview on condition that he remains anonymous.

16. 'Mixed reaction to opinion poll,' Sunday Nation, November 11, 2007 p. 18

17. Robert M. Worcester (1993), 'Public and elite attitudes to environment issues.' International Journal of Opinion Research, 5(4), p. 315-334.

18. Orange Democratic Movement Press statement, December 18, 2007.

19. PNU carried half-page advertisements with this message.

20. Wa-Mungai, Mbugua (2007) 'Tusker Project Fame: Ethnic States, Popular Flows.' Journal of Eastern African Studies, 1(3), p. 338-358.

21. All pollsters however voiced their credibility and non-alignment with any political party.

22. www.nationmedia.com/elections. December 7, 2007 [Not available].

23. Interview with Caroline Kariuki, a registered voter.

\section{AUTHOR}

\section{PATRICK MUTAHI}

The author is the Director of Africa Policy Institute, East and Horn of Africa Office, Nairobi. 